\title{
PENGARUH REWARD TERHADAP MOTIVASI BELAJAR AKIDAH AKHLAK SISWA DI MIN SIHADABUAN PADANGSIDIMPUAN
}

\author{
Rini Agustini \\ ( Dosen PGMI Fakultas Agama Islam, UMTS )
}

\begin{abstract}
Reward is an Islamic educational tool that can motivate students to learn. However, the motivation of students to learn Aqidah Morals in MIN Sihadabuan looks declining. This can be seen from students who are less excited when following the learning process so that the value of repetition obtained by learners is under the KKM. Therefore, giving rewards is one that can be done by a teacher to encourage students to get a good achievement. Reward is an effective and strategic way when used in accordance with the principles of learning to stimulate learners to be more active in learning and to develop the potential of learners. Thus it is expected that the motivation of learners in the learning process will increase and increase.

The problem is whether there is a significant influence on the motivation to motivate learning Aqidah Akhlak students simultaneously in MIN Sihadabuan Padangsidimpuan? The purpose of this study is to determine whether there is a significant influence on the motivation of motivation to learn Aqidah Akhlak students simultaneously in MIN Sihadabuan Padangsidimpuan.

The results of this study there is a significant effect of reward on student learning motivation of 0.715 , the contribution of $51.1225 \%$ the remaining $48.8775 \%$ is determined by other variables. This provides information that rewards have a strong effect on student learning motivation. This provides information that rewards simultaneously have a strong influence on student learning motivation.
\end{abstract}

Keywords: Reward and motivation to learn.

\section{A. Pendahuluan}

Pendidikan mempunyai peranan penting dalam menentukan perkembangan dan perwujudan diri individu, terutama bagi pembangunan bangsa dan negara. Tujuan pendidikan pada umumnya ialah menyediakan lingkungan yang memungkinkan anak didik untuk mengembangkan bakat dan kemampuannya secara optimal, sehingga ia dapat mewujudkan dirinya dan berfungsi sepenuhnya, sesuai dengan kebutuhan pribadinya dan kebutuhan masyarakat. Oleh karena itu, disini pendidik dituntut untuk dapat 
mengembangkan bakat dan kemampuan anak didik dengan cara memberikan dorongan-dorongan yang dapat meningkatkan motivasi anak didik sehingga mereka bisa mengembangkan bakat dan kemampuan mereka sendiri.

Dalam psikologi behaviorisme, motif adalah suatu pernyataan jiwa yang kompleks di dalam suatu organism yang mengarahkan tingkah laku atau perbuatan ke suatu tujuan atau perangsang. Motivasi pada eksistensinya sangat penting khususnya dalam pengembangan atau pengaktualisasian diri seorang individu. Dalam proses kerjanya maka motivasi itu mempunyai kerja sebagai berikut, yakni: menggerakkan, mengarahkan, dan menopang tingkah laku manusia. Jadi jelas bahwa motivasi merupakan satu potensi individu yang harus menjadi landasan bagi proses pembinaan dan pengembangan kepribadian.

Setiap perbuatan, termasuk perbuatan belajar didorong oleh sesuatu atau beberapa motif. Motif atau biasa juga disebut dorongan atau kebutuhan merupakan sesuatu tenaga yang berada pada diri individu atau siswa yang mendorongnya untuk berbuat mencapai suatu tujuan. Tenaga pendorong atau motif pada seseorang mungkin cukup besar sehingga tanpa motivasi dari luar dia sudah bisa berbuat. Orang atau siswa tersebut memiliki motif internal. Pada orang atau siswa lain, tenaga pendorong ini kecil sekali, sehingga ia membutuhkan motivasi dari luar, yaitu dari guru, orang tua, teman, bukubuku dan sebagainya. Orang atau siswa seperti itu memerlukan motif eksternal. $^{1}$

Adapun latar belakang masalah dalam penelitian ini adalah dilandasi oleh empat landasan yaitu landasan filosofis, teologis, teoritis, dan faktual. Adapun landasan yang pertama adalah landasan filosofis yang terdapat dalam UU SISDIKNAS No. 20 Tahun 2003, bab II pasal 3 mengenai Tujuan Pendidikan Nasional yang bunyinya:

"Pendidikan nasional bertujuan mengembangkan kemampuan dan pembinaan watak serta peradaban bangsa yang bermartabat dalam rangka

${ }^{1}$ R. Ibrahim dan Nana Syaodih S., Perencanaan Pengajaran, (Jakarta: Rineka Cipta, 2010), h. 27-28 
mencerdaskan kehidupan bangsa, bertujuan untuk berkembangnya potensi peserta didik agar menjadi manusia yang beriman dan bertakwa kepada Tuhan Yang Maha Esa, berilmu, cakap, kreatif, mandiri, dan menjadi warga negara yang demokratis serta bertanggung jawab". ${ }^{2}$

Jadi, sudah jelas terlihat di atas dari tujuan pendidikan nasional dalam rangka mencerdaskan kehidupan bangsa yang merupakan tujuan akhir dari pendidikan. Untuk itu, dalam mencapai tujuan akhir tersebut dibutuhkan tujuan instruksional dari PBM (Proses Belajar Mengajar). Salah satu faktor agar tujuan tersebut dapat tercapai adalah dengan memotivasi siswa untuk belajar.

Motivasi belajar timbul karena dua faktor, yaitu faktor intrinsik berupa hasrat dan keinginan berhasil dan dorongan kebutuhan belajar, harapan akan cita-cita. Selanjutnya faktor ekstrinsiknya adalah adanya penghargaan, lingkungan belajar yang kondusif, dan kegiatan belajar yang menarik. ${ }^{3}$

Dalam penelitian ini, yang menjadi salah satu cara yang dapat memotivasi siswa untuk lebih giat belajar adalah reward (ganjaran). Reward termasuk dalam motivasi ekstrinsik yang berada diluar diri siswa tersebut.

Reward merupakan cara yang efektif dan strategis bila digunakan sesuai dengan prinsip-prinsip belajar untuk merangsang peserta didik agar lebih giat dalam pembelajaran dan untuk mengembangkan potensi peserta didik. Reward menurut Saodah Nasution, berarti: 1) imbalan; upah, 2) memberi upah. ${ }^{4}$ Ganjaran sebagai alat pendidikan yang cukup penting dalam memotivasi siswa agar lebih giat dalam belajar. Al-Ghazali berpendapat, bahwa jika anak melakukan perbuatan yang baik dan berakhlak terpuji, hendaknya ia dimuliakan dan dipuji. Jika mungkin, ia diberi hadiah yang

${ }^{2}$ Undang-undang Sistem Pendidikan Nasional No. 20 Tahun 2003, (Jakarta: Sinar Grafika, 2009), h. 7

${ }^{3}$ Hamzah B. Uno, Teori Motivasi \& Pengukuran: Analisis di Bidang Pendidikan, (Jakarta: Bumi Aksara, 2015), h. 23

${ }^{4}$ Saodah, Nasution, Kamus Umum Lengkap Inggris-Indonesia, Indonesia-Inggris, (Jakarta: Mutiara Sumber Widya, 1989), h. 215-216 
baik. Dipuji dihadapan orang-orang penting dan berkedudukan, sebagai motivasi baginya. ${ }^{5}$

Kedua, landasan teologis reward (ganjaran) merupakan alat dalam pendidikan Islam. Ganjaran merupakan perlakuan menyenangkan yang diterima peserta didik dari pendidiknya sebagai buah dari prestasi dan perbuatan baik yang telah dicapai atau dilakukan oleh peserta didik. ${ }^{6}$ Berkaitan dengan konsep ganjaran, Allah SWT berfirman dalam Q.S. AlZalzalah ayat 7 yang berbunyi:

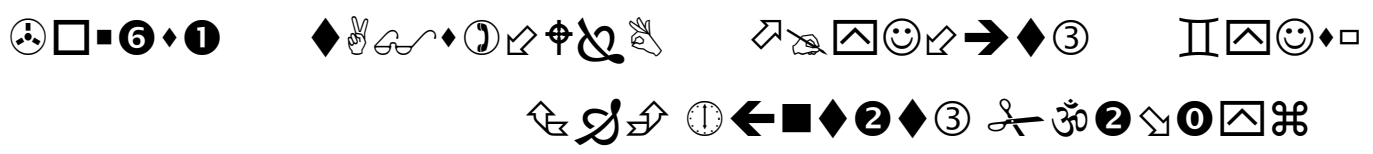

Artinya: "Barang siapa yang melakukan kebaikan seberat dzarrahpun, niscaya dia akan melihat (balasan) nya,"”7(Q.S. Al-Zalzalah: 7).

Dari ayat di atas dapat dipahami bahwa semua diperlakukan secara adil, maka barang siapa yang mengerjakan kebaikan seberat dzarrah yakni butir debu sekalipun, kapan dan di mana pun niscaya dia akan melihatnya. Kata dzarrah ada yang memahaminya dalam arti semut yang kecil pada awal kehidupannya, atau kepala semut. Ada juga yang menyatakan dia adalah debu yang terlihat beterbangan dicelah cahaya matahari yang masuk melalui lubang dan jendela. Sebenarnya kata ini digunakan untuk menggambarkan sesuatu terkecil, sehingga apapun makna kebahasaannya, yang jelas adalah ayat ini menegaskan bahwa manusia akan melihat amal perbuatannya sekecil apapun amal itu. ${ }^{8}$

Maksudnya maka barang siapa yang melakukan kebaikan di dunia seberat biji dzarrah maka ia akan ia akan diberi pahala. Adapun penafsiran dzarrah yaitu seberat semut hitam. ${ }^{9}$ Adapun penafsiran Q.S. al-Zalzalah: 7

${ }^{5}$ Fathiyyah Hasan Sulaiman, Alam Pikiran Al-Ghazali Mengenai Pendidikan dan Ilmu, Terj. A.A.Dahlan dkk,(Bandung: CV. Diponegoro, 1986), h. 80

${ }^{6}$ Dja'far Siddik, Konsep Dasar Ilmu Pendidikan Islam (Bandung: Citapustaka Media, 2006), hlm. 145.

${ }^{7}$ Departemen Agama RI, Al-Qur'an dan Terjemahannya, (Jakarta: Cahaya Intan Cemerlang, 2009), h. 599

${ }^{8}$ M. Quraish Shihab, Tafsir Al-Misbah: Pesan, Kesan dan Keserasian Al-Quran, (Jakarta: Lentera Hati, 2002), Volume 15, h. 455

${ }^{9}$ Muhammad Jamaluddin Qasim, Tafsir Qasim, (Beirut: Darul Kutub Ilmiyah, TT), h. 526 
dijelaskan bahwa Allah pasti akan membalas dan ini merupakan ketetapan Allah. ${ }^{10}$

Konsep reward merupakan pengukuran pendidikan bagi kualitas fungsional edukatif siswa yang berprestasi dan bermasalah. Hadiah, penghargaan, dan cendera mata adalah urgen diberikan kepada mereka yang berprestasi. Sebaliknya, hukuman sebagai vaksinasi dini dalam konteks pendidikan pun layak diberikan kepada mereka yang bermasalah. ${ }^{11}$

Pembelajaran efektif, bukan membuat murid pusing, akan tetapi bagaimana tujuan pembelajaran dapat tercapai dengan mudah dan menyenangkan. Motivasi sebagai gejala psikologi menjadi amat penting dalam pengembangan dan pembinaan potensi individu karena potensi motivasi ini menjadi satu kekuatan seseorang untuk melakukan sesuai dengan yang diinginkan serta tingkat kekuatannya untuk mencapai keinginan tersebut.

Ketiga, landasan teoritis. Adapun teori yang digunakan dalam penelitian ini adalah teori behavior dari Skinner. Skinner, adalah salah seorang tokoh yang sangat berperan dalam teori pembelajaran perilaku yang telah mempelajari hubungan antara tingkah laku dan konsekuensinya mengemukakan bahwa belajar merupakan perubahan perilaku. Prinsip yang paling penting dari teori belajar perilaku adalah bahwa perilaku berubah sesuai dengan konsekuensi-konsekuensi langsung dari perilaku tersebut. Konsekuensi yang menyenangkan akan memperkuat perilaku, sedangkan konsekuensi-konsekuensi yang tidak menyenagkan akan memperlemah perilaku. Dengan kata lain konsekuensi-konsekuensi yang menyenangkan akan meningkatkan frekuensi seseorang untuk melakukan perilaku yang serupa.

Konsekuensi yang menyenangkan disebut penguat (reinforcer). Penggunaan konsekuensi-konsekuensi yang menyenangkan adalah untuk

${ }^{10} \mathrm{Abu}$ Bakar Muhammad bin Abdullah, Ahkamul Quran, (Beirut: Darul Kutub Ilmiyah, TT), h. 437

${ }^{11}$ A. Malik Fadjar, Holistika Pemikiran Pendidikan, (Jakarta: PT RajaGrafindo Persada, 2005), h. 201 
mengubah perilaku sering disebut pengkondisian operan (operant conditioning). Dengan diberikannya penguatan, maka akan terjadi perubahan tingkah laku. ${ }^{12}$ Kemudian Skinner juga mengemukakan efek negatif dan positif dari reinforcement.

A positive reinforcer, is a stimulus that strengthens the probability of a response when it is added to a situation, whereas a negative reinforcer is one that strengthens response probability when it is removed from the situation. ${ }^{13}$

Reinforcer positif merupakan stimulus yang memperkuat kemungkinan tanggapan yang ketika ditambahkan untuk suatu situasi, sedangkan reinforcer negatif adalah sesuatu yang memperkuat kemungkinan tanggapan ketika terjadi perubahan.

Berkaitan dengan teori di atas jelas terlihat bahwa pemberian reward dalam proses pembelajaran itu penting, sebab siswa akan termotivasi untuk lebih giat lagi belajar karena adanya pemberian reward, sebab siswa merasa bahwa hasil kerja kerasnya untuk mencapai prestasi dihargai.

Keempat, landasan faktual. Berdasarkan pengamatan yang dilakukan peneliti di MIN Sihadabuan Padangsidimpuan, bahwa guru Aqidah Akhlak sudah menerapkan reward. Hal ini dapat dilihat dari bentuk reward yang diberikan guru Aqidah Akhlak kepada siswa adalah berupa peringkat dan simbol, seperti ranking, centang tanda benar yang diberikan kepada peserta didik jika peserta didik berhasil mengerjakan tugas yang diberikan oleh guru. Selain itu, guru juga menyuruh peserta didik ke depan untuk menulis jawaban dari tugas yang bagus yang sudah dikerjakan. Penguatan secara verbal seperti pujian, contohnya: "bagus, bagus sekali, benar, benar sekali” yang diberikan kepada semua peserta didik yang dapat menjawab pertanyaan atau soal-soal yang diberikan oleh guru. Berbentuk sentuhan, seperti menyalam siswa yang berprestasi, ini dilakukan pada saat anak mendapat ranking di sekolah. Sementara kalau berbentuk hadiah itu biasanya seperti buku tulis, piagam dan piala kepada peserta didik yang berprestasi yang diserahkan di lapangan

\footnotetext{
${ }^{12}$ Trianto, Mendesain Model Pembelajaran Inovatif-Progresif: Konsep, Landasan, dan Implementasinya pada Kurikulum Tingkat Satuan Pendidikan (KTSP), (Jakarta: Kencana, 2012), h. $39-40$

${ }^{13}$ Henry Clay Lindgren \& W. Newton Suter, Educational Psychology In The Classroom: Seventh Edition, (America, Brooks/Cole Publishing Company, 1985), h. 145-146
} 
sekolah dengan mengumumkan nama-nama perserta didik yang berprestasi. Selanjutnya reward yang diterapkan guru Aqidah Akhlak bertujuan untuk meningkatkan motivasi ekstrinsik siswa akan tetapi secara faktual bahwa motivasi belajar siswa masih rendah. Hal ini dapat dilihat dari kelakuankelakuan peserta didik ketika mengikuti proses pembelajaran. Seperti mengobrol dengan teman sebangku pada saat proses belajar mengajar sedang berlangsung, duduknya menyender ke dinding tembok kelas jika peserta didiknya duduk di samping dinding tembok, lesu, dan lain sebagainya. Jadi, di sini sudah terlihat jelas bahwa peserta didik kurang bersemangat ketika mengikuti proses pembelajaran sehingga nilai ulangan yang didapatkan oleh peserta didik berada di bawah KKM. Adapun KKM untuk mata pelajaran Aqidah Akhlak adalah 80. Untuk itu, agar motivasi pesera didik tidak menurun lagi, guru Aqidah Akhlak memberikan reward dalam proses pembelajaran. Dengan demikian diharapkan motivasi peserta didik dalam proses pembelajaran akan meningkat dan bertambah.

Berdasarkan hal di atas, maka penulis ingin mengkaji hal tersebut, sehingga merumuskan judul : "Pengaruh Reward Terhadap Motivasi Belajar Aqidah Akhlak Siswa Di MIN Sihadabuan Padangsidimpuan”.

\section{B. Landasan Teori}

\section{Motivasi Belajar}

\section{a. Pengertian Motivasi}

Pembelajaran efektif, bukan membuat murid pusing, akan tetapi bagaimana tujuan pembelajaran dapat tercapai dengan mudah dan menyenangkan. Motivasi berpangkal dari kata motif yang dapat diartikan sebagai daya penggerak yang ada di dalam diri seseorang untuk melakukan aktivitas-aktivitas tertentu demi tercapainya suatu tujuan. Bahkan motif dapat diartikan sebagai suatu kondisi intern 
(kesiapsiagaan). ${ }^{14}$ Jadi, motif itu merupakan suatu penggerak di dalam diri manusia untuk melaksanakan suatu aktivitas agar tercapainya suatu tujuan.

Menurut Mc Donald yang dikutip oleh Oemar Hamalik bahwa: Motivation is an energy change within the person characterized by affective arousal and anticipatory goal reaction.

"Motivasi adalah perubahan energy dalam diri (pribadi) seseorang yang ditandai dengan timbulnya perasaan dan reaksi untuk mencapai tujuan”. Di dalam perumusan ini kita dapat lihat, bahwa ada tiga unsur yang saling berkaitan, yaitu sebagai berikut :

1) Motivasi dimulai dari adanya perubahan energi dalam pribadi. Perubahan-perubahan dalam motivasi timbul dari perubahanperubahan tertentu di dalam sistem neuropisiologis dalam organisme manusia, misalnya karena terjadi perubahan dalam sistem pencernaan maka timbul motif lapar. Tapi ada juga perubahan energi yang tidak di ketahui.

2) Motivasi ditandai dengan timbulnya perasaan affective arousal. Mula-mula merupakan ketegangan psikologis, lalu merupakan suasana emosi. Suasana emosi ini menimbulkan kelakukan yang bermotif. Perubahan ini mungkin bias dan mungkin juga tidak, kita hanya dapat melihatnya dalam perbuatan. Seorang terlibat dalam suatu diskusi, karena dia merasa tertarik pada masalah yang akan di bicarakan maka suaranya akan timbul dan kata-katanya akan lancar dan cepat akan keluar.

3) Motivasi ditandai dengan reaksi-reaksi untuk mencapai tujuan. Pribadi yang bermotivasi respons-respons yang tertuju kearah suatu tujuan. Respons-respons itu bertujuan untuk mengurangi ketegangan yang disebabkan oleh perubahan energi dalam dirinya. Setiap respons merupakan suatu langkah kearah mencapai tujuan. Misalnya

${ }^{14}$ Veithzal Rivai Zainal dan Fauzi Bahar, Islamic Education Management: Dari Teoti ke Praktik (Mengelola Pendidikan Secara Profesional dalam Perspektif Islam, (Jakarta: Rajawali Pers, 2013), h. 361 
si A ingin mendapat hadiah maka ia akan belajar, mengikuti ceramah, bertanya, membaca buku, dan mengikuti tes. ${ }^{15}$

Motivasi (motivation) adalah keseluruhan dorongan, keinginan, kebutuhan, dan daya yang sejenis yang mengarahkan perilaku. Motivasi juga diartikan satu variabel penyelang yang digunakan untuk menimbulkan faktor-faktor tertentu di dalam organisme, yang membangkitkan, mengelola, mempertahankan, dan menyalurkan tingkah laku menuju satu sasaran. Dalam diri seseorang, motivasi berfungsi sebagai pendorong kemampuan, usaha, keinginan, menentukan arah dan menyeleksi tingkah laku. ${ }^{16}$

Jadi, dapat dipahami bahwa motivasi adalah segala daya atau usaha-usaha yang mendorong seseorang untuk melakukan sesuatu sehingga ia mencapai hasil atau tujuan tertentu. Manusia tidak mengerjakan sesuatu aktivitas kecuali jika ada tujuan dibalik pekerjaan yang dikerjakannya itu. Tidak ada seseorang yang mengerjakan pekerjaan tertentu kalau ia tidak ada tujuan yang ingin dicapainya dengan perbuatan itu.

\section{b. Strategi Menumbuhkan Motivasi Belajar}

Ada beberapa strategi yang bisa digunakan oleh guru untuk menumbuhkan motivasi belajar murid menurut Veithzal Rivai Zainal dan Fauzi Bahar, sebagai berikut: ${ }^{17}$

1) Menjelaskan tujuan belajar ke peserta didik. Pada permulaan belajar mengajar seharusnya terlebih dahulu seorang guru menjelaskan mengenai Tujuan Instruksional Khusus yang akan dicapainya kepada siswa. Makin jelas tujuan maka makin besar pula motivasi dalam belajar.

${ }^{15}$ Oemar Hamalik, Proses BelajarMengajar, (Jakarta: Bumi Aksara, 2004), Cet. ke-3,h.

16 Abdul Mujib dan Jusuf Mudzakir, Nuansa-nuansa Psikologi Islami, (Jakarta: PT RajaGrafindo Persada, 2001), h. 243

${ }^{17}$ Veithzal Rivai Zainal dan Fauzi Bahar, op.cit., h. 361-362 
2) Berikan hadiah untuk murid yang berprestasi. Hal ini akan memacu semangat mereka untuk bisa belajar lebih giat lagi. Di samping itu, murid yang belum berprestasi akan termotivasi untuk bisa mengejar murid yang berprestasi.

3) Saingan/kompetisi. Guru berusaha mengadakan persaingan di antara muridnya untuk meningkatkan prestasi belajarnya, berusaha memperbaiki hasil prestasi yang telah dicapai sebelumnya.

4) Pujian. Sudah sepantasnya murid yang berprestasi untuk diberikan penghargaan atau pujian. Tentunya pujian yang bersifat membangun.

5) Hukuman. Hukuman diberikan kepada murid yang berbuat kesalahan saat proses belajar mengajar. Hukuman ini diberikan dengan harapan agar murid tersebut mau mengubah diri dan berusaha memacu motivasi belajarnya.

6) Membangkitkan dorongan kepada anak didik untuk belajar. Strateginya adalah dengan memberikan perhatian maksimal ke peserta didik.

7) Membentuk kebiasaan belajar yang baik.

8) Membantu kesulitan belajar anak didik secara individual maupun kelompok.

9) Menggunakan metode yang bervariasi.

10) Menggunakan media yang baik dan sesuai dengan tujuan pembelajaran.

Paparan di atas dapat dipahami bahwa seorang pendidik dituntut untuk dapat memilih strategi yang tepat untuk digunakan dalam proses pembelajaran sehingga strategi yang dipilih tersebut diharapkan bisa meningkatkan motivasi peserta didik dalam mengikuti proses pembelajaran.

\section{Reward}

\section{a. Pengertian Reward}


Reward dalam Kamus Inggris Indonesia menurut John M. Echols dan Hassan Shadily, adalah: a) Ganjaran, hadiah, menawarkan hadiah, hadiah atas usahanya, ganjaran sebagai seorang guru. b) Upah, pahala, mendapat upah/pahala/ganjaran. c) Diberi hadiah untuk usaha-usahanya. d) Memberikan penghargaan. e) Menghadiahi, menghadiahkan. f) Membalas. ${ }^{18}$ Ganjaran dalam Kamus Istilah Pendidikan dan Umum adalah hadiah, pembalas jasa, alat pendidikan yang diberikan kepada murid-murid yang telah dapat mencapai prestasi baik. ${ }^{19}$

Sementara menurut C.P Chaplin bahwa reward (ganjaran) adalah sebarang perangsang, situasi atau pernyataan lisan yang bisa menghasilkan kepuasan atau menambah kemungkinan suatu perbuatan yang dipelajari. Sinonim dengan reinforcement. Secara umum, para psikolog behavioristik lebih menyukai istilah reinforcement (penguatan), karena reward (ganjaran) memiliki sedikit konotasi mentalistik dan berasosiasi dengan kepuasan, yaitu satu keadaan batiniah yang tidak dapat diamati. Sebagian besar psikolog, jika menyangkut pribadi anakanak, khususnya dalam situasi pendidikan menggunakan istilah reward. ${ }^{20}$

Reward dalam Kamus Psikologi adalah ganjaran, upah, hadiah, pahala: konsekuensi positif yang mengikuti sebuah tindakan; imbalan yang diterima dengan menjalankan perilaku tertentu. Biasanya berfungsi sebagai penguat respons. ${ }^{21}$

Apakah maksud pendidik memberi ganjaran kepada anak didiknya? Jawaban pertanyaan itu tidak sukar. Ganjaran adalah salah satu alat pendidikan. Jadi, dengan sendirinya maksud ganjaran itu ialah sebagai alat untuk mendidik anak-anak supaya anak dapat merasa senang karena perbuatan atau pekerjaannya mendapat penghargaan. Umumnya, anak

\footnotetext{
${ }^{18} \mathrm{John}$ M. Echols dan Hassan Shadily, Kamus Inggris Indonesia: An English-Indonesia Dictionary, (Jakarta: PT Gramedia Pustaka Utama, 2003), Cet. ke-XXV, h. 485

${ }^{19}$ Sastrapradja, Kamus Istilah Pendidikan dan Umum, (Surabaya: Usaha Nasional, 1981), h. 169

${ }^{20}$ C. P Chaplin, Kamus Lengkap Psikologi, terj. Kartini Kartono, (Jakarta: Rajawali Pers, 1981), Cet. Ke-7, h. 436

${ }^{21}$ Kartini Kartono dan Dali Gulo, Kamus Psikologi, (Bandung: Pionir Jaya, 1987), h. 425
} 
mengetahui bahwa pekerjaan atau perbuatannya yang menyebabkan ia mendapat ganjaran itu baik. Selanjutnya pendidik bermaksud juga supaya dengan ganjaran itu anak menjadi lebih giat lagi usahanya untuk memperbaiki atau mempertinggi prestasi yang telah dapat dicapainya. Dengan kata lain, anak menjadi lebih keras kemauannya untuk bekerja atau berbuat yang lebih baik lagi. Jadi, maksud ganjaran itu yang terpenting bukanlah hasilnya yang dicapai seorang anak, melainkan dengan hasil yang telah dicapai anak itu pendidik bertujuan membentuk kata hati dan kemauan yang lebih baik dan lebih keras pada anak itu.

Siapakah yang berhak mendapat ganjaran? Jika ganjaran itu ialah alat mendidik, ganjaran tidak boleh menjadi bersifat sebagai upah. "Upah" ialah sesuatu yang mempunyai nilai sebagai "ganti rugi" dari suatu pekerjaan atau suatu jasa. "Upah" adalah sebagai pembayar suatu tenaga, pikiran, atau pekerjaan yang telah dilakukan oleh seseorang. Besar-kecilnya upah memiliki perbandingan yang tertentu dengan beratringannya pekerjaan atau banyak-sedikitnya hasil yang telah dicapai. Sedangkan ganjaran sebagai alat pendidikan tidak demikian halnya. Belum tentu anak yang terpandai atau terbaik pekerjaannya di sekolah mendapat ganjaran dari gurunya. Seorang anak yang memang pandai, dan selalu menunjukkan hasil pekerjaan yang baik, tidak perlu selalu mendapat ganjaran. Sebab, jika demikian halnya, ganjaran itu sudah berubah sifatnya menjadi "upah". Jika ganjaran itu sudah berubah sifat menjadi upah, ganjaran itu tidak lagi bernilai mendidik. Anak mau bekerja giat dan berlaku baik karena mengharapkan upah. Jika tidak ada upah atau sesuatu yang diharapkannya, mungkin anak itu berbuat "seenaknya" saja. Seorang anak yang pada suatu ketika menunjukkan hasil yang lebih dari pada biasanya, mungkin sangat baik diberi ganjaran. Dalam hal ini guru hendaklah bijaksana, jangan sampai ganjaran itu 
menimbulkan iri hati pada anak lain yang merasa dirinya lebih baik atau lebih pandai, tetapi tidak mendapat ganjaran. ${ }^{22}$

\section{b. Macam-macam Hadiah}

Adapun macam-macam hadiah menurut Suharsimi Arikunto, adalah sebagai berikut: ${ }^{23}$

1) Peringkat dan Simbol-simbol Lain

Bentuk hadiah yang paling lazim digunakan adalah peringkat huruf dan angka meskipun simbol-simbol lain seperti tanda-tanda bintang, centang, tanda benar dan lain-lain kadang-kadang juga digunakan untuk siswa-siswa Sekolah Dasar dan Menengah. Pemberian peringkat dengan cara yang betul dan adil akan merupakan hadiah yang paling tepat jika dikaitkan langsung dengan usaha siswa, prestasi dan kemampuan. Oleh karena itu sebaiknya penggunaan simbol dapat sebanyak-banyaknya digunakan dengan berbagai segi keberhasilan tugas siswa.

2) Penghargaan

Hadiah ini dapat berupa berbagai hal yang mempunyai arti adanya “perhatian" kepada siswa. Misalnya saja siswa berhasil membuat pekerjaan tangan atau hasil karya yang lain. Karena hasil tersebut sangat menonjolkan dibandingkan dengan hasil karya siswa lain, maka hasil tersebut dipamerkan di depan kelas atau dipertontonkan kepada siswa-siswa lain di sekolahnya atau bahkan mungkin kepada masyarakat sekitar dalam kesempatan pameran sekolah.

3) Hadiah Berupa Kegiatan

\footnotetext{
${ }^{22}$ Ngalim Purwanto, Ilmu Pendidikan Teoritis dan Praktis, (Bandung: Remaja Rosdakarya, 1994), Cet. ke-7, h, 170-171

${ }^{23}$ Suharsimi Arikunto, Manajemen Pengajaran Secara Manusiawi, (Jakarta: Rineka cipta, 2003), h. 160-164
} 
Ada kalanya sesuatu pekerjaan, tugas ataupun kegiatan-kegiatan lain akan merupakan dambaan bagi siswa untuk memperoleh kesempatan untuk melakukannya. Contoh-contoh untuk peristiwa ini dapat disajikan di bawah ini.

Contoh 1: Pada waktu guru matematika memberikan soal-soal untuk dikerjakan, di bawah dituliskan pengumuman seperti'Barang siapa yang dapat menyelesaikan hitungan sebelum waktu yang ditentukan habis, diperbolehkan membantu petugas perpustakaan untuk mengatur buku-buku baru". Dalam pengumuman ini terkandung sebuah kegiatan yang sangat menarik bagi siswa, khususnya mereka yang dapat dikategorikan sebagai "kutu buku". Meskipun disuruh bekerja tetapi mereka menyukainya karena akan mendapat kesempatan mengenal buku-buku sebelum siswa-siswa yang lain melihatnya.

4) Hadiah Berupa Benda

Dalam memberikan hadiah berupa benda, guru harus bisa mempertimbangkan dengan cermat dalam pemberian hadiah yang berupa benda ini, maka guru harus menentukan hanya untuk anakanak yang betul-betul terpilih.

\section{c. Hal-hal yang Harus Dipertimbangkan dalam Memberikan Hadiah}

Beberapa hal yang perlu dijadikan bahan pertimbangan dalam memberikan hadiah berupa benda antara lain;

1) Hadiah tersebut harus benar-benar berhubungan dengan prestasi yang dicapai. Misalnya jika siswa berhasil baik dalam mengerjakan tugas pelajaran maka hadiah yang tepat adalah buku tulis atau alat-alat tulis yang lain. Jika siswa memperoleh sukses dalam bermain badminton, maka hadiah berupa raket atau "shuttle cock" kiranya lebih tepat.

2) Hadiah berupa benda sebaiknya disesuaikan dengan kebutuhan siswa yang menerima. Bagi siswa yang berasal dari keluarga dengan keadaan ekonomi kurang mampu, mungkin hadiah berupa tabanas akan lebih baik dibandingkan dengan hadiah yang semestinya berupa 
benda yang mahal harganya. Namun untuk siswa yang sudah tidak kekurangan uang, benda yang kurang berartipun, misalnya vandel, lambang sekolah, plaket, dan lain-lain akan dipandang sebagai sesuatu yang membanggakan dirinya.

3) Hadiah yang berupa benda sebaiknya tidak perlu terlalu mahal. Alasan untuk pertimbangan ini adalah:

a) Akan membiasakan anak pada penghargaan yang terlalu tinggi sehingga mungkin lain kali tidak akan memandang sebagai "hadiah" untuk sesuatu yang kurang berharga.

b) Mungkin sekali keuangan sekolah tidak selamanya dalam keadaan "baik" sehingga tidak selalu mampu memberikan hadiah dengan harga yang tinggi. ${ }^{24}$

Edward Lee Thorndike yang dikutip oleh Netti Hartati dengan teori law of effect, mengemukakan bahwa perilaku yang menimbulkan kesenangan akan mengakibatkan perilak terulang kembali, sebaliknya tingkah laku yang mendatangkan kesenangan akan menjadikan pelakunya meninggalkan perilaku tersebut. ${ }^{25}$

\section{Pembahasan dan Hasil Penelitian}

\section{Pengujian Hipotesis}

Untuk melakukan pengujian hipotesis yang diajukan dalam penelitian ini, sebagaimana yang diolah menggunakan rumus regresi ganda. Dalam kajian teoritis yang dilakukan pada bagian terdahulu, penulis mempunyai dugaan yang kuat bahwa "Terdapat Pengaruh Reward Terhadap Motivasi Belajar Aqidah Akhlak Siswa di MIN Sihadabuan Padangsidimpuan".

${ }^{24}$ Ibid., h. 165

${ }^{25}$ Netty Hartati, dkk, Islam dan Psikologi, (Jakarta: RajaGrafindo Persada, 2004), h. 57 
Oleh karena itu, dilakukan pengujian dalam penelitian ini merupakan hipotesis alternatif, artinya sejauhmana "Terdapat Pengaruh Reward Terhadap Motivasi Belajar Aqidah Akhlak Siswa di MIN Sihadabuan Padangsidimpuan".

Untuk menguji hipotesis, maka nilai $r$ hitung $\left(r_{x y}\right)$ dikonsultasikan kepada $\mathrm{r}$ tabel $\left(\mathrm{r}_{\mathrm{t}}\right)$, yaitu $\mathrm{N}-\mathrm{nr}=90-2=88$. Pada tabel "r" Product Moment ditemukan nilai $\mathrm{r}$ tabel $\left(\mathrm{r}_{\mathrm{t}}\right)$ untuk $\mathrm{df}=88$ pada tingkat kepercayaan 5\% sebesar 0,213. Dengan demikian hipotesis yang berbunyi "terdapat hubungan yang signifikan antara reward terhadap motivasi belajar Aqidah Akhlak Siswa di MIN Sihadabuan Padangsidimpuan" diterima karena $r$ hitung $\left(r_{x y}=0,715>r_{t}=0,213\right)$. Artinya semakin banyak reward yang diterapkan oleh guru maka motivasi belajar siswa di MIN Sihadabuan Padangsidimpuan akan semakin tinggi.

Konstanta sebesar 1,355 menyatakan bahwa jika tidak ada kenaikan nilai variabel reward (X), maka motivasi belajar Aqidah Akhlak siswa (Y) adalah 0,715 . Koefisien regresi sebesar 0,608 menyatakan bahwa setiap penambahan (karena tanda + ) satu skor atau nilai kemampuan akan memberikan peningkatan skor sebesar $\mathrm{a}+\mathrm{b}+1=0,608+1.355+1=2,963$.

Terlihat pada kolom sig (signifikansi) pada tabel 4.15 terdapat nilai 0,0001 atau probabilitas jauh di bawah 0,05 karena nilai $t_{\text {hitung }}>$ nilai $t_{\text {tabel }}$ atau 9,594> 1,671, maka Ho ditolak artinya koefisien regresi signifikan atau reward berpengaruh secara signifikan terhadap motivasi belajar Aqidah Akhlak siswa di MIN Sihadabuan Padangsidimpuan. 


\section{Penutup}

\section{Kesimpulan}

Berdasarkan uraian pada beberapa bab terdahulu sebelumnya, maka penulis dapat mengambil kesimpulan sebagai berikut:

a. Reward berpengaruh secara signifikan terhadap motivasi belajar siswa. Besarnya pengaruh variabel reward terhadap motivasi belajar siswa adalah 0,715 sedangkan kontribusi variabel $\mathrm{X} 1$ terhadap $\mathrm{Y}$ sebesar $51,1225 \%$ kemudian sisanya 48,8775\% ditentukan oleh variabel lain. Informasi ini memberikan keterangan bahwa variabel reward memberikan pengaruh kuat terhadap motivasi belajar siswa.

\section{Saran-Saran}

Data empiris telah membuktikan bahwa reward dapat memotivasi belajar Aqidah Akhlak siswa di MIN Sihadabuan Padangsidimpuan. Berdasarkan penelitian di lapangan, peneliti mengemukakan beberapa saran diantaranya:

a. Bagi para siswa di MIN Sihadabuan Padangsidimpuan

1) Hendaknya siswa terus termotivasi untuk lebih giat dan semangat dalam belajar dan pembelajaran agar tercapainya tujuan pendidikan terutama dalam mata pelajaran Aqidah Akhlak.

2) Siswa diharapkan untuk lebih aktif lagi dalam mengikuti proses pembelajaran terutama dalam mata pelajaran Aqidah Akhlak agar kriteria ketuntasan minimal yang ditetapkan dapat tercapai. 
b. Bagi Guru Bidang Studi Aqidah Akhlak

1) Hendaknya guru Aqidah Akhlak lebih memahami bagaimana cara membangkitkan motivasi belajar siswa.

2) Hendaknya guru Aqidah Akhlak lebih mendalami bagaimana cara memberikan reward yang tepat guna untuk meningkatkan motivasi siswa dalam belajar.

c. Kepada Kepala Sekolah di MIN Sihadabuan Padangsidimpuan

1) Hendaknya kepala sekolah di MIN Sihadabuan Padangsidimpuan selalu membekali dan menambah pengetahuan para guru tentang cara menerapkan reward dengan yang baik.

2) Hendaknya kepala sekolah di MIN Sihadabuan Padangsidimpuan selalu memberikan arahan, nasihat, dan motivasi kepada para siswa agar selalu giat dan aktif dalam belajar dan pembelajaran.

d. Bagi Peneliti

1) Bagi peneliti ada kemungkinan kelemahan yang terjadi dalam pelaksanaan penelitian ini. Oleh karena itu,masih perlu diadakan penelitian lebih lanjut dengan memperbesar objek penelitian.

2) Bagi peneliti yang ingin meneliti lebih lanjut lagi pada masalah dalam penelitian ini supaya memperhatikan variabel lain yang mungkin turut berpengaruh terhadap motivasi belajar siswa. 


\section{E. Daftar Pustaka}

R. Ibrahim dan Nana Syaodih S., Perencanaan Pengajaran, Jakarta: Rineka Cipta, 2010.

Undang-undang Sistem Pendidikan Nasional No. 20 Tahun 2003, Jakarta: Sinar Grafika, 2009.

Hamzah B. Uno, Teori Motivasi \& Pengukuran: Analisis di Bidang Pendidikan, Jakarta: Bumi Aksara, 2015.

Saodah, Nasution, Kamus Umum Lengkap Inggris-Indonesia, IndonesiaInggris, Jakarta: Mutiara Sumber Widya, 1989.

Fathiyyah Hasan Sulaiman, Alam Pikiran Al-Ghazali Mengenai Pendidikan dan Ilmu, Terj. A.A.Dahlan dkk, Bandung: CV. Diponegoro, 1986

Dja'far Siddik, Konsep Dasar Ilmu Pendidikan Islam Bandung: Citapustaka Media, 2006.

Departemen Agama RI, Al-Qur'an dan Terjemahannya, Jakarta: Cahaya Intan Cemerlang, 2009.

M. Quraish Shihab, Tafsir Al-Misbah: Pesan, Kesan dan Keserasian AlQuran, Jakarta: Lentera Hati, 2002.

Muhammad Jamaluddin Qasim, Tafsir Qasim, Beirut: Darul Kutub Ilmiyah, TT.

Abu Bakar Muhammad bin Abdullah, Ahkamul Quran, Beirut: Darul Kutub Ilmiyah, TT.

A. Malik Fadjar, Holistika Pemikiran Pendidikan, Jakarta: PT RajaGrafindo Persada, 2005.

Trianto, Mendesain Model Pembelajaran Inovatif-Progresif: Konsep, Landasan, dan Implementasinya pada Kurikulum Tingkat Satuan Pendidikan (KTSP), Jakarta: Kencana, 2012.

Henry Clay Lindgren \& W. Newton Suter, Educational Psychology In The Classroom: Seventh Edition, America, Brooks/Cole Publishing Company, 1985. 
Veithzal Rivai Zainal dan Fauzi Bahar, Islamic Education Management: Dari Teoti ke Praktik (Mengelola Pendidikan Secara Profesional dalam Perspektif Islam, Jakarta: Rajawali Pers, 2013.

Oemar Hamalik, Proses BelajarMengajar, Jakarta: Bumi Aksara, 2004.

Abdul Mujib dan Jusuf Mudzakir, Nuansa-nuansa Psikologi Islami, Jakarta: PT RajaGrafindo Persada, 2001.

John M. Echols dan Hassan Shadily, Kamus Inggris Indonesia: An EnglishIndonesia Dictionary, Jakarta: PT Gramedia Pustaka Utama, 2003.

Sastrapradja, Kamus Istilah Pendidikan dan Umum, Surabaya: Usaha Nasional, 1981.

C. P Chaplin, Kamus Lengkap Psikologi, terj. Kartini Kartono, Jakarta: Rajawali Pers, 1981.

Kartini Kartono dan Dali Gulo, Kamus Psikologi, Bandung: Pionir Jaya, 1987.

Ngalim Purwanto, Ilmu Pendidikan Teoritis dan Praktis, Bandung: Remaja Rosdakarya, 1994.

Suharsimi Arikunto, Manajemen Pengajaran Secara Manusiawi, Jakarta: Rineka cipta, 2003.

Netty Hartati, dkk, Islam dan Psikologi, Jakarta: RajaGrafindo Persada, 2004. 